\title{
Analisa Efektivitas Bank Sampah sebagai Alternatif Pengelolaan Sampah Dalam Upaya Menuju Smart City di Kota Tangerang Selatan
}

\author{
Gunartin*) \\ Email : Gunartin9472@gmail.com
}

\begin{abstract}
ABSTRAK
Analisa Efektivitas Bank Sampah sebagai Alternatif Pengelolaan Sampah Dalam Upaya Menuju Smart City di Kota Tangerang Selatan. Penelitian ini difokuskan pada efektivitas bank sampah dalam pengelolaan sampah dalam upaya menuju konsep smart citydi Kota Tangerang Selatan.Adapun tujuan dalam penelitian ini yaitu untuk menggambarkan keberadaan bank sampah di Kota Tangerang Selatan dan menganalisa efektivitas bank sampah dalam pengelolaan sampah sebagai upaya menuju konsep smart city.Penelitian ini menggunakan metode kualitatif dengan pendekatan analisa deskriptif. Penelitian ini menggunakan teknik analisa data deskriptif dari data yang telah dikumpulkan dan dilakukan secara triangulasi yaitu merupakan gabungan cara pengumpulan data dengan mengkolaborasikan beberapa cara pengumpulan data dari informan dan peneliti sebagai instrumennya. Peneliti menggunakan metode analisa deskriptif, yaitu suatu analisa yang dimaksudkan untuk menjelaskan data dari satu variabel yang diteliti. Sumber data penelitian adalah data primer dan skunder dengan teknik pengambilan sampel menggunakan purposive sampling. Lokasi penelitian di Kota Tangerang Selatan, Provinsi Banten. Dari hasil penelitian diperoleh informasi bahwa keberadaan bank sampah di Tangerang Selatan mengalami perkembangan yang baik dari tahun 2012-2018, yaitu 239 bank sampah dengan 8.162 nasabah bank sampah. Sedangkan efektivitas bank sampah sejauh ini dipandang kurang efektif karena pengelolaan sampah ini baru sebatas memindahkan dan memilah sampah sesuai jenisnya, belum sampai pengelolaan sampah sehingga menjadi bebas sampah.Memang bank sampah membuat sambah bernilai ekonomis dan memberikan keuntungan bagi penghasil sampah tetapi belum mengatasi permasalahan sampah.
\end{abstract}

Kata kunci: sampah,bank sampah, smart city

\section{ABSTRACT}

The effectiveness of waste banks in waste management in an effort towards the concept of smart city in South Tangerang City. This research is focused on the effectiveness of waste banks in waste management in an effort towards the concept of smart city in South Tangerang City. The purpose of this study is to describe the existence of a waste bank in South Tangerang City and analyze the effectiveness of waste banks in waste management as an effort towards a smart city concept. This study uses a qualitative method with a descriptive analysis approach. This study uses descriptive data analysis techniques from the data that has been collected. In this study conducted in triangulation which is a combination of ways of collecting data by collaborating several ways of collecting data from informants and researchers as instruments. The researcher used descriptive analysis method, which is an analysis intended to explain data from one variable studied. Sources of research data are primary and secondary data with the sampling technique using purposive sampling. Research location in South Tangerang City, Banten Province. From the results of the study it was obtained information that the presence of waste banks in South Tangerang experienced good development from 2012-2018, namely 239 waste banks with 8,162 garbage bank customers. Whereas the effectiveness of the waste bank has so far been considered less effective because the management of this waste is only limited to moving and sorting waste according to its type, not to waste management so that it becomes waste-free. Indeed, garbage banks make economic value and provide benefits for waste producers but have not overcome the garbage problem.

Keywords: waste, waste banks, smart city

*) Dosen Universitas Pamulang 


\section{PENDAHULUAN}

\section{A. Latar Belakang}

Sebagai kota urban, peningkatan vplume penduduk di Tangerang Selatan (Tangsel) melaju dengan cepat. Tumbuh kembangnya ekonomi di daerah perkotaan dikarenakandaerah kota menawarkan daya tarik yang tinggi kepada masyarakat yang berasal dari daerah. Konsekuensi dari pertambahan jumlah penduduk yang melaju pesat, mengakibatkan tingkat konsumsi masyarakat perkotaan meningkat,yang pada akhirnya akan berdampak pada volume sampah. (Suryani,2014).Pertumbuhan penduduk di Kota Tangerang Selatan yang mengakibatkan meningkatnya tingkat konsumsi masyarakat, dan berdampak pada meningkatnya jumlah sampah. Upaya penanganan sampah di wilayah perkotaan masih merupakan problem yang harus dicari solusinya oleh pemerintah setempat. Timbunan sampah menjadi pemandangan di sudut Kota Tangsel sehingga mengurangi keindahan kota yang sedang tumbuh dan berkembang. Timbunan sampah masih kelihatan di tepi-tepi jalan, di pojokpojok pasar, ditepi-tepi sungai dan lahan-lahan kosong.

Berdasarkan data BPS Tangerang Selatan 2018 dapat diinformasikan bahwa periode tahun 2010 - 2017 jumlah penduduk Tangsel ada penambahan jumlah penduduk sebesar 346.395 jiwa sehingga pada tahun 2017 penduduk Tangsel berjumlah 1.644.899 jiwa artinya terjadi pertumbuhan penduduk $26,67 \%$ atau mencapai $3,81 \%$ rata-rata per tahun. Dari data tersebut dapat dikatakan laju pertumbuhan penduduk Tangerang Selatan masih katagori tinggi di Propinsi Banten bahkan menduduki peringkat nomor dua kota terpadat.

Berdasarkan tingkat pertumbuhan di atas, berdampak pada pola konsumsi yang tinggi dan tentu menghasikan sampah yang tinggi pula. Masyarakat Kota Tangerang Selatan menghasilkan sampah dalam kegiatan setiap harinya katagori tinggiyaitu mencapai 880 ton pada tahun 2016 dan sekitar 1000 ton pada tahun 2017 (sumber Dinas Lingkungan Hidup Tangerang Selatan). Pemkot Tangsel kian dihadapkan persoalan pelik karena ketinggian tumpukan sampah hingga belasan meter. Ditengah keadaan yang rumit, timbul ekspektasi, permasalahan sampah solusinya dengan animo masyarakat yaitu membentuk suatu wadah/organisasi yaitu bank sampah. Kehadiran bank sampah pada 2012 memberikan harapan lebih efisien dan efektif karena keterlibatan warga secara aktif dengan harapan volume sampah dapat berkurang. Per tahun 2017 jumlah bank sampah 208 dengan jumlah nasabah sekitar 4.000 orang. Tingginya kesadaran masyarakat akan permasalah sampah dan keberadaan bank sampah diharapkan mampu mengatasi persoalan sampah sekaligus menciptakan lingkungan bersih. Kehadiran bank sampah merupakan bentuk kearifan lokal. Masyarakat sudah memiliki kesadaran dan kepedulian untuk mengubah sampah bernilai lebih ekonomis.

Masyarakat dalam pengelolaan sampah menerapkan strategi 3R (Reuse, Reduce, Recycle). Program bank sampah pada konsepnya merupakan rekayasa sosial (social engineering) untuk mendorong masyarakat melakukan pemilahan sampah. Implementasi program bank sampah ini mampu memberikan wujud riil menambah pendapatan keluargasekaligus menyelamatkan lingkungan masyarakat dalam manajemen operasi bank sampah dan investasi dalam bentuk tabungan (Kementrian Lingkungan Hidup, 2011). Persoalannya, sejauh mana efektifitas bank sampah ini dapat membantu mengatasi 
permasalahan sampah? Karena dengan terus bertambahnya bank sampah pada kenyataannya masih banyak timbunan sampah di tempat-tempat umum, pinngir jalan, tepi sungai dan lahanlahan kosong.

Dengan usia yang masih relatif muda Kota Tangerang Selatan yang lahir 29 Oktober 2008 dan predikat sebagai kota urban tentu banyak permasalahan yang terjadi, yang tentunya membutuhkan perhatian dari semua pihak untuk membangun Kota Tangerang Selatan. Sebagai upaya percepatan pembangunan Kota Tangerang Selatan, pemerintah harus membuat kebijakan-kebijakan yang mensinergikan program pemerintah dengan pihak swasta dan masyarakat. Karena pembangunan kota menjadi tanggung jawab pemerintah bersamasemua lapisan warga. Untuk menjadi kota cerdas (smart city) ditinjau dari komponen smart environment tentu butuh tata kelola kota, diantaranya:1) lingkungan dikelola secarasustainable; 2) mengurangi penggunaan energy, melalui inovasi teknologi; dan 3) konservasi energi dan daur ulangmaterial.

\section{B. Fokus Penelitian}

Mengaju pada fenomena yang dipaparkan pada latar belakang di atas, bahwa bank sampah di Tangerang Selatan sudah diprakarsai sejak 2012 sebagai upaya menangani permasalahan sampah tetapi tumpukan sampah masih terihat dimana-mana, maka pada penelitian ini difokuskan mendeskrisipkan perkembangan / keberadaan bank sampah dan efektivitas bank sampah dalam pengelolaan sampah.

\section{Rumusan Masalah}

Mengacu fokus penelitian di atas, maka masalah dirumuskansebagai berikut:

1. Bagaimana keberadaan bank sampah di Kota Tangerang Selatan?

2. Bagaimana efektivitas bank sampah sebagai alternative pengelolaan sampah di Tangerang Selatan?

\section{Tujuan Penelitian}

Pengelolaan lingkungan bersih, sehat dan nyaman, akan sangat mendukung terwujudnya smart city, karena lingkungan bersih, sehat dan nyamaadalah bagian komponen dari smart city, yaitu smart environment. Untuk mewujudkan lingkungan kota bersih, sehat dan nyaman, bank sampah hadir sebagai alternatif memberikan solusi pengelolaan sampah agar minim sampah. Maka dari itu, tujuan penelitian ini, untuk mendeskripsikan keberadaan / perkembangan bank sampah dan efektivitas bank sampah sebagai pilihanmanajemen sampah di Tangerang Selatan.

\section{TINJAUAN PUSTAKA}

\section{A. Sampah}

Sampah merupakan hasil limbahaktivitas manusia setiap hari maupun proses alami.Sampah dibagi menjadi dua jenis (Dinas Lingkungan Hidup Tangsel, 2018):

1. Sampah Organik 
JURNAL ILMIAH ILMU MANAJEMEN

Sampah organikyaitu sisa kegiatan makluk hidup dan dapat diurai secara alami, seperti sisa makanan dan sisa organisme.

2. Sampah Non Organik

Sampak non organik adalah limbahyangsusah diuraikan, misal plastik, kaca beling, logam. Termasuk dalam sampah non organik, ada sampah jenis Bahan Berbahaya dan Beracun (B3) yaitu bahan berbahaya bagi makhluk hidup serta lingkungannya. Untuk mengenal sampah B3, memiliki karakteristik yaitu:

a. Gampang meledak di suhu standar, juga dengan reaksi kimia dan fisika, contoh tabung gas, botol beralkohol;

b. Mudah terbakarpada titik nyala kurang dari 60 derajat Celsius contoh cat, thinner

c. Bersifat reaktif,contoh gas

d. Mengandung racun, contoh pupuk kimia, obat nyamuk

e. Infeksius contoh jarum suntik

f. Bersifat korosir yaitu limbah yang menyebabkan iritasi (terbakarpada kulit), contoh air accu.

Sedangkan menurut Notoadmodjo (2007) menurut jenisnya sampah dapat dibedakan berdasarkan: 1) kandungan zat kimia; 2) sulit atau mudahterbakar; 3) sifat/ciri sampah.

\section{B. Bank Sampah}

Bank sampah merupakan lembaga yang cara kerjanya hampir sama seperti lembaga bank, dengan menghimpun sampah dari masyarakat berupa haban yang tidak terpakai atau sampah nonorganik, bernilai ekonomis untuk menggerakkan partisipasi masyarakat dalam berperilaku bijak dalam mengelola sampah khususnya pilah pilih sampah dan menambah nilai ekonomi dari sampah. Bank sampah adalah sutu program yang bertujuan untuk membentuk kemitraan dan pemberdayaan kepada masyarakat dengan sistem manajerial yang operasionalnya dilakukan oleh masyarakat itu sendiri, sehingga bank sampah dapat menjadi suatu program untuk mengajak masyarakat dalam merubah perilaku masyarakat untuk lebih peduli dan menghargai sampah yang dihasilkan.

Bank sampah dikonsep sedemikian rupa untuk memberikan manfaat antara lain: 1) membantu mengatasi permasalahan sampah; 2) alternative sumber penghasilan keluarga tambahan dari sampah yang ditabung; 3) membuat sampah menjadi barang ekonomis; 4) menyadarkan masyarakat akan pentingnya kebersihan; 5) menumbuhkan entrepreneurshipdaur ulang sampah; dan 6) membuat lingkungan lebih bersih dan sehat. Selain manfaat yang begitu besar, bank sampah juga mempunyai tujuan: 1) mewujudkan lingkungan bersih, sehat dan nyaman; 2) meminimalkan volume sampah ke Tempat Pembuangan Akhir (TPA); 3) merubah kebiasaan masyarakat untuk berperilaku ekonomis; 4) mengedukasi masyarakat peduli lingkungan yang bersih,sehat dan nyaman; dan 5) memberikan keuntungan penghasil sampah.

\section{Smart City (Kota Cerdas)}

Konsep menuju smart city perlu dukungan dari berbagai pihak. Pemkot Tangsel bersama-sama masyarakat saling bersinergi mewujudkan Kota Tangerang Selatan sebagai kota cerdas (smart city). Seperti halnya permasalahan sampah yang dihadapi Kota Tangerang 
Selatan, perlu upaya dari Pemkot setempat untuk mencari jalan keluar yang efektif dan efisien. Sampah merupakan bagian dari lingkungan hidup. Salah satu dimensi smart city yang terkait dengan lingkungan adalah smart environment (lingkungan pintar) yang berkelanjutan seta bersumber daya ekonomi.

Smart environment dapat diartikan kenyamanan, kebersihan serta kesehatan lingkungan secara berkelanjutan sehingga meningkatkan sumber daya ekonomi bagi masyarakat dari segi teknologi informasi. Atau dapat diartikan sebagai lingkungan yang bersih tertata, sehat dan harmonis sehingga memberi rasa nyaman bagi masyarakat, membuat kota lebih efisien dan layak huni. Masyarakat merupakan komponen penting dalam pencapaian smart city. Maka dari itu dalam pengelolaan sampah keterlibatan masyarakat menjadi faktor utama untuk keberhasilan dalam mewujudkan terciptanya smart city.

\section{METODE PENELITIAN}

A. Pendekatan Penelitian

Pendekatan penelitian yaitu metode kualitatif yaitu penelitian yang dimaksudkan untuk memaknai gejala tentang subyek penelitian (Moleong, 2011). Mendeskripsikan gejala/fenomena subjek penelitian secara mendalam dari hasil pengumpulan data merupakan pendekatan yang dilakukau pada penelitian ini yaitu pendekatan deskriptif. Menurut Sugiono (2015) penelitian kualitatif adalah metode penelitian untuk mendalami subjek pada kondisi natural dan peneliti berperan sebagai instrumen kunci.

Penelitian ini yang akan diamati dan dideskripsikan adalah efektifitas bank sampah sebagai alternatif pengelolaan sampah di Kota Tangerang Selatan, dan peneliti sebagai instrument kunci dimana peneliti sendiri yang melakukan observasi, pengumpulan data, menggali informasi, menganalisa hingga menarik kesimpulan.

\section{B. Sumber Data}

Penelitiananalisa efektivitas bank sampah sebagai alternatif pengeloaan sampahdalam upaya menuju konsep smart city, membutuhkan data yang meliputi;

1. Data primer

Data primer merupakan data langsung yang bersumber dari informan sehubungan dengan relevansi kompetensi (Sugiyono, 2012). Data primer pada penelitian ini bersumber dari informan kunci yaitu Dinas Lingkungan Hidup, Diskominfo, Pengelola Bank Sampah dan nasabah bank sampah

2. Data sekunder

Informasi berupa dokumen, foto, dan catatan lain yang dapat dipakai sebagai sumber data (Sugiyono, 2012).Pada Penelitian ini, data skunder diperoleh dari Badan Pusat Statistik Tangsel, Blue Print Tangsel, media cetak

\section{Populasi dan Sampel}

Penelitian ini tidak mengutamakan besarnya populasi dansampel, artinya sampel boleh jadi sangat terbatas.Teknik purposivesampling menjaditeknik pilihan dalam menetapkan informan, dengan tujuan agar perolehan data sesuai dengan kebutuhan.Teknik yang 
merupakan teknik penentuan informan dengan berbagai pertimbangan untuk memperoleh informasi yang diperlukan. Pertimbangan dimaksudkan untuk memudahkan peneliti memahami fenomena yang menjadi fokus penelitian (Sugiyono, 2012).Sedangkan sampel penelitian kualitatif dapat sebagai nara sumber, partisipan atau informan, yaitu Dinas Lingkungan Hidup, Diskominfo, Pengelola Bank Sampah, dan nasabah bank sampah.

\section{Teknik Pengumpulan Data}

Pengumpulan data diartikan proses yang dilaksanakan oleh peneliti untuk menjaring fenomena, informasi serta kondisi subyek penelitian sesuai lingkup penelitian. Untuk kepentingan tersebut diperlukan strategi pengumpulan data agar tujuan penelitian dapat dicapai.Penelitian ini menggunakan teknik pengumpulan data observasi dan wawancara, peneliti sebagai instrument kuncinya.Untuk keabsahan data digunakan triangulasi sumber yaitu penggalian kebenaran melalui berbagai metode dan sumber perolehan data (Sugiono, 2005). Uji keakurasian data dilakukan dengan croscek data dari sumber data yang berbeda. Selanjutnya data diidentifikasi, dikatagorikan, direduksidan ditarik kesimpulan.

\section{E. Teknik Analisa Data}

Teknik analisa data merupakan cara mendeskripsikan teknik analisis yang dipakai menganalisa perolehan informasi (Sanusi Anwar, 2011). Peneliti menggunakan metode analisa statistik deskriptif yaitu analisa untuk menjelaskan data suatu variabel yang diteliti. Peneliti ingin mendeskripsikan perkembangan bank sampah dan efektivitas bank sampah sebagai alternatif pengelolaan sampah di Kota Tangerang Selatan dalam upaya menuju konsep smart city.

\section{HASIL DAN PEMBAHASAN}

\section{A. Sampah Di Tangerang Selatan}

Sampah yang tidak tertangani secara optimal dapat berimbas ke lingkungan dan kesehatan, yaitu: 1) sampah sebagai tempat berkembangbiaknya vector penyakit; 2) tempat berkembangbiaknya kuman penyakit; dan 3) pencemaran lingkungan dan penyebab banjir. Untuk itu sampah sangat perlu penanganan dan pengelolaan yang maksimal, dengan mempertimbangkan volume sampah yang dihasilkan terus bertambah. Pengelolaan sampah telah di Undang-Undang kan agar masyarakat sadar dan patuh pada Undang Undang.

Kebijakan pengelolaan sampah di wilayah perkotaaan di atur dalam Undang-Undang Nomor 18 Tahun 2008 tentang Pengelolaan Sampah. Hal ini merupakan suatu tonggak baru bagi masyarakat untuk solusi penanganan permasalahan sampah. Pengelolaan sampah difokuskan pada dua kegiatan, dengan cara:

1. Meminimalisir sampah, dengan perilaku minim sampah (reduce), pemanfaatan lagi (reuse), dan proses kembali (recycle)

2. Pengolahan sampah,meliputi kegiatan:
a. Dipilah berdasarkan karakter sampah
b. Dikumpulkandan sementara ditampung di bank sampah
c. Diangkut dengan memindahkan sampah ke TPA
d. Pemroresan untuk diubah sifatnya sampah. 
Dari hasil wawancara dengan informan kunci Ketua Bidang Pengeloaan Sampah Dinas Lingkungan Hidup Kota Tangerang Selatan mencatat setiap keluarga menghasilkan sampah antara 0,8 kg sampai $2 \mathrm{~kg}$ per harinya. Jumlah sampah yang dihasilkan oleh penduduk Kota Tangsel dalam persentase disajikan pada Tabel 4.1 sebagai berkut:

Tabel 4.1. Identifikasi Jenis Sampah (dalam persentase)

\begin{tabular}{|c|l|c|}
\hline No & \multicolumn{1}{|c|}{ Jenis Sampah } & Persentase (\%) \\
\hline 1 & Sampah Organik & 43,39 \\
\hline 2 & Sampah Non Organik & 26,52 \\
\hline 3 & Sampah Bahan Berbahaya dan Beracun (sampah B3) & 14,45 \\
\hline 4 & Sampah lainnya $\quad$ Total & 15,64 \\
\hline & \multicolumn{1}{|c|}{} \\
\hline
\end{tabular}

Sumber: Dinas Lingkungan Hidup, 2018

Kota Tangerang Selatan setiap harinya jumlah sampah yang dihasilkan katagoritinggi denganjumlah 880 ton/hari di tahun 2017 dan tahun 2018 mencapai 1.000 ton per hari (sumber DLH Kota Tangerang Selatan). Tentu hal ini menjadi permasalahan yang pelik yang sedang dihadapi Kota Tangsel. Maka dari itu perlu strategi bagaimana caranya agar sampah yang notabene merupakan sumber masalah dapat menjadi sumber manfaat bagi masyarakat.

Namun masyarakat tampaknya belum sadar betul akan pengelolaan sampah. Sampah non organik merupakan sampah yang sulit diuraikan oleh alam salah satu contohnya adalah plastik.Plastik tidak dapat diuraikan seperti halnya sampah organik.Oleh karena itu, Dinas Lingkungan Hidup Kota Tangsel membuat solusi untuk mengurangi sampah non organik dengan membentuk bank sampah. Dengan pengelolaan yang baik dan sinergisitas antara masyarakat dengan bank sampah maka sampah non organik yang tidak berguna akan memiliki nilai ekonomis.

\section{B. Bank Sampah di Kota Tangerang Selatan.}

Peliknya permasalahan sampah yang jumlahnya terus bertambah, Kepala Bidang Persampahan dari Dinas Lingkungan Hidup Pemkot Tangsel berhasil mencetuskan dan memperkenalkan program bank sampah kepada masyarakat. Bank sampah adalah program manajemen sampah dengan sistem penanganan sampah terpadu yaitu pengurangan volume sampah (reduce), guna ulang (reuse), serta (daur ulang (recycle) atau sering disingkat 3R. Program bank sampah mulai digerakkan di lingkungan Kota Tangsel sejak tahun 2012. Bank sampah diberikan pembinaan dan bintek tentang pengelolaan sampah, pengolahan kembali dan urban farming. Pemkot Tangsel juga juga memfasilitasi kelengkapan aktivitas setiap bank sampah dengan timbangan, buku tabungan nasabah dan neon box sebagai identitas bank sampah.

Kehadiran bank sampah mendapat respon positif dari masyarakat. Bank sampah dirasa efektif dalam pengelolaan sampah karena melibatkan warga secara aktif. Dengan keterlibatan masyarakat secara aktif menunjukkan kesadaran masyarakat dan hal ini sangat membantu mengatasi permasalahan sampah.. Pernyataan Ketua Forum Komunikasi Bank Sampah 
(FORKAS) Tangsel pada Juni 2017 jumlah bank sampah mencapai 208 bank sampah dengan nasabah 4.000 orang. Dan yang lebih penting, selain dapat mengubah sampah sehingga mempunyai nilai guna secara ekonomi, bank sampah diharapkan mampu menjadi motor penggerak merealisasi kota yang bersih dan cerdas. Bank sampah merupakan pintu akses untuk menyelaraskan program Kota Tangsel dalam pengelolaan sampah. Di bawah kendali Forkas sampah menjadi lebih mudah dijual karena pembeli langsung datang ke lokasi. Sampah yang sudah dipilah oleh masyarakat langsung ditimbang untuk dijual. Sampah yang memiliki nilai jual yaitu sampah plastic, kertas, beling/kaca dan logam

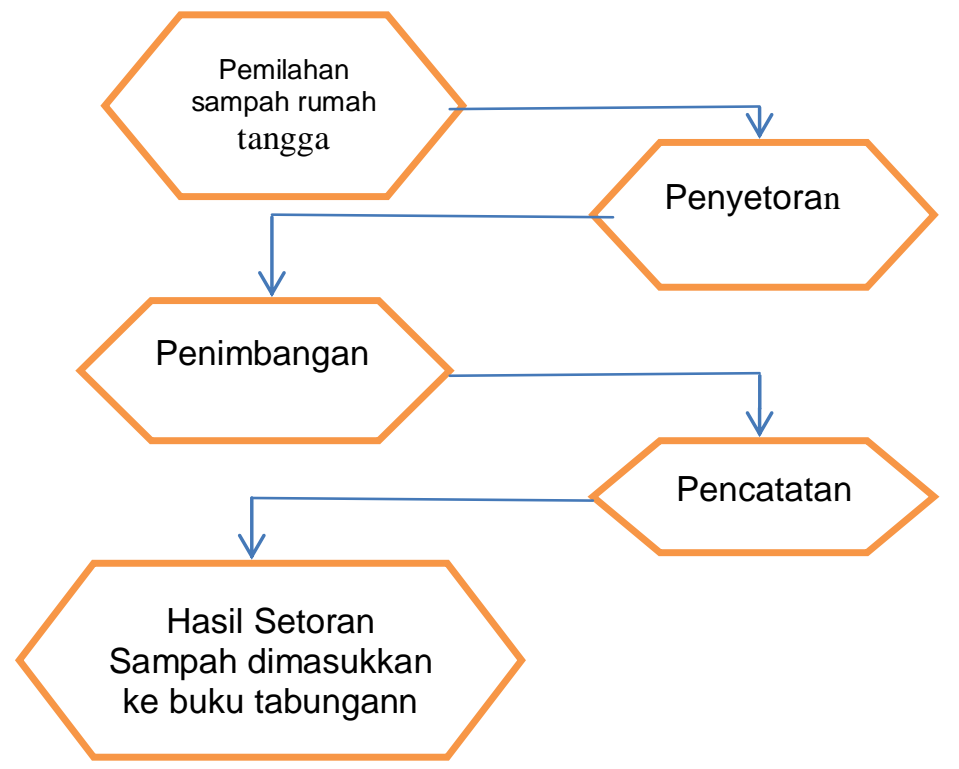

Gambar 1 : Flowchart Mekanisme Penyetoran Sampah ke Bank Sampah

\section{Efektivitas Bank Sampah Sebagai Alternatif Pengelolaan Sampah di Kota Tangsel.}

Berdasarkan hasil wawancara dengan informan kunci satu, dari Dinas Lingkungan Hidup bahwa peran bank sampah sangat membantu dalam pengurangan sampah terutama sampah non organik.Selain dapat mengurangi sampah juga merupakan pendapatan keluarga bagi nasabah bank sampah. Tetapi ini tidak menyelesaikan permasalahan sampah yang dari hari ke hari semakin bertambah.Keberadaan bank sampah sementara ini baru mengurangi sampah tetapi belum menyelesaikan permasalahan sampah. Artinya keberadaan bank sampah sebatas memindahkan sampah dari rumah tangga ke bank sampah, atau setidaknya mengurangi sampah di Tempat Pembuangan Akhir (TPA).

Informan kunci satu, juga menambahkan bahwa pengelolaan sampah seharusnya dimulai dari rumah tangga yaitu dengan program minim sampah. Program minim sampah tidak akan bisa diwujudkan tanpa didukung kesadaran masyarakan sebagai sumber/penghasil sampah. Kehadiran bank sampah dipandang efektif karena melibatkan masyarakat secara aktif dengan harapan dapat mengurangi volume sampah di TPA berbagai wilayah Kota Tangsel.Kesadaran masyarakat dalam mengelola sampah dapat meringankan permasalahansampah (Ketua Forum Komunikasi Bank Sampah Tangerang Selatan). 
Pandangan serupa juga diperoleh dari informan kunci dua, yaitu Pengolah Data Statistis Dinas Lingkungan Hidup, menurutnya, bank sampah sejak tahun 2012 di Kota Tangerang selatan jumlahnya terus bertambah hingga tahun 2017 telah mencapai 208 bank sampah dengan nasabah bank sampah sekitar 4.000 nasabah, dan tahun 2018 jumlah bank sampah di Tangsel mengalami kenaikan menjadi 239 dengan jumlah bank sampah 8.162 nasabah. Data bank sampah Kota Tangerang Selatan tahun 2018 disajikan pada Tabel 4.2

Tabel 4.2 Data Bank sampah Kota Tangerang Selatan
\begin{tabular}{|r|l|r|r|}
\hline No.. & \multicolumn{1}{|c|}{ Kecamatan } & Jumlah Bank Sampah & \multicolumn{1}{c|}{$\begin{array}{c}\text { Jumlah } \\
\text { nasabah }\end{array}$} \\
\hline 1 & Pamulang & 89 & 3.507 \\
\hline 2 & Setu & 26 & 1.219 \\
\hline 3 & Ciputat & 36 & 740 \\
\hline 4 & Ciputat Timur & 36 & 1.599 \\
\hline 5 & Serpong & 11 & 333 \\
\hline 6 & Serpong Utara & 13 & 132 \\
\hline 7 & Pondok Aren & 28 & 632 \\
\hline & Total & $\mathbf{2 3 9}$ & $\mathbf{8 , 1 6 2}$ \\
\hline
\end{tabular}

Sumber: Data Statistik Dinas Lingkungan Hidup

Awalnya, bank sampah diharapkan dapat membantu mengatasi permasalahan sampah.Permasalahannya pertumbuhan bank sampah belum sebanding dengan lajunya jumlah sampah per hari yang dihasilkan masyarakat Tangerang Selatan.Koordinator Bank Sampah Kecamatan Ciputat selaku informantiga menguratarakan bahwa kehadiran bank sampah merupakan kearifan local, artinya, secara sadar masyarakat memiliki kepedulian mewujudkan lingkungan bersih, sehat dan nyaman. Selain mengubah sampah bernilai lebih ekonomis, bank sampah juga menjadi gerakan bersama mewujudkan kota yang bersih, juga menjadi akses menyelaraskan dengan program Pemkot Tangsel mengatasi sampah.

Pendapat yang sama juga disampaikan Kepala Bidang Persampahan Dinas Lingkungan Hidup Tangsel bahwa perubahan perilaku masyarakat akan sadar lingkungan, dapat mengubah paradigm masyarakat yaitu sampah bukan musibah melainkan berkah apabila disikapi dengan bijak. Keterlibatan masyarakat sebagai mitra Dinas Lingkungan Hidup dalam pengelolaan sampah, yaitu dengan berperan aktif dan berpartisipasi pada bank sampah dapat membantu mewujudkan kota yang sehat, bersih dan kreatif sebagai upaya menuju smart city.

Berbeda dengan pendapat beberapa informan dari Dinas Lingkungan Hidup, hasil wawancara dengan pengelola Bank Sampah Berlian Ciputat, bahwa keberadaan bank sampah justru menstimulus masyarakat untuk menghasilkan sampah karena sampah bisa menjadi uang.Masyarakat tidak berorientasi pada mengatasi permasalahan sampah agar minim sampah melainkan mengumpulkan sampah untuk dijadikan uang, sehingga dalam hal ini hanya terjadi pemindahan sampah dari rumah tangga ke bank sampah dan menghasilkan uang.

Dari hasil penelitian dapat dianalisa bahwa bank sampah cukup membantu dalam pengelolaan sampah, serta menjadi penggerak masyarakat akan lingkungan yang bersih dan 
sehat. Sayangnya, tumbuhnya kesadaran masyarakat atas lingkungan yang bersih dan sehat bukan berangkat dari kesadaran akan peduli lingkungan melainkan karean ada nilai ekonomis yang ditawarkan dari sampat tersebut dan menjadi uang. Artinya, kalau tidak ada imbalan dari mengumpulkan dan memilah sampah maka program bank sampah yang notabene mampu menjadi solusi alternative pengelolaan sampah tidak dapat diwujudkan.

Berdasarkan informasi hasil wawancara, dari beberapa sumber, dapat peneliti tarik kesimpulan bahwa pengelolaan sampah yang efektif dapat optimal apabila program minim sampah dapat diberlakukan oleh semua masyarakat Tangsel untuk mewujudkan lingkungan bebas sampah. Program minim sampah dimulai dari rumah tangga dengan cara berusaha untuk tidak menghasilkan sampah dalam kegiatan sehari-hari, karena sampah yang paling banyak didominasi dari sampah dapur. Cara yang dapat dilakukan oleh rumah tangga untuk minim sampah, diantaranya:

1. Belanja kebutuhan sehari-hari membawa tempat sendiri agar tidak menghasilkan sampah kantong plastik. Contoh beli ayam / tahu membawa Tupperware sendiri.

2. Beli makanan jadi bawa tempat sendiri, contoh beli bakso bawa rantang, beli nasi goreng bawa piring sendiri.

3. Memasak, sesuai kebutuhan anggota rumah tangga, artinya tidak membiarkan makanan tersisa dan menjadi sampah.

4. Sampah dipilah yang organik dicincang untuk jadi pupuk kompos dengan bantuan biocommpon agar tidak menimbulkan bau dan muncul belatung, sedangkan yang non organik dikumpulkan, dipilah sesuai jenisnya dan disetorkan ke bank sampah secara beerkala.

Jika kegiatan minim sampah ini sudah dilakukan setiap rumah tangga, dimana sudah diminimalisir dari rumah tangga dan langsung dilakukan tindakan atas sampah organik dan non organik maka permasalahan sampah akan dapat diatasi dengan baik. Dalam hal ini butuh sinergi antara masyarakat dengan Pemerintahan Kota Tangsel untuk mewujudkan pengelolaan sampah dengan baik dan bijak dengan motto "Kota Tangerang Selatan Bebas Sampah".

Kenyataannya, meskipun bank sampah ditinjau dari jumlahnya mengalami perkembangan yang baik dari tahun 2012-2018, yaitu terdapat 239 bank sampah dengan 8.162 nasabah bank sampah, permasalahan sampah belum dapat diatasi dengan baik. Beberapa factor yang mempengaruhi yaitu;

1. Kebijakan pengelolaan dan penanganan sampah terpusat di Kementrian Lingkungan Hidup dan Kehutanan, bukan kewenangan daerah kota/kabupaten setempat, sehingga Pemkot setempat tidak bisa mengambil kebijakan atau keputusan terkait dengan pengelolaan dan penanganan sampah.

2. Masih terkendala pada Perda Rencana Tata Ruang dan Wilayah (RTRW) Tangerang Selatan, sehingga teknologi sanitary landfield tidak cukup untuk menampung sampah 1.200 ton per hari dengan terbatasnya lahan.

3. Kesadaran masyarakat untuk mengelolala sampah dari rumah tangga masih minim, hal ini dapat dilihat dari masih banyaknya sampah yang dibuang di sembarang tempat seperti sungai, pinggir jalan, pasar tradisional, lahan-lahan kosong.

4. Asumsi masyarakat bahwa masyarakat sudah membayar iuran kebersihan, sehingga masyarakat lebih bergantung pada tukang kebersihan atau pengangkut sampah, 
JURNAL ILMIAH ILMU MANAJEMEN

5. Sampah belum dipilah berdasarkan jenis organik atau non organik, sehingga sampai di TPS kondisi sampah sudah rusak, campur dan sulit untuk dipisahkan, sehingga pada akhirnya muara sampah di TPA. Sedikit demi sedikit lama-lama menjadi bukit sampah.

6. Keterbatasan lahan untuk pengelolaan sampah dengan Teknologi Insenerator, selain itu juga perlu mendapatkan sertifikat dari Kementrian Linkungan Hidup dan Kehutanan untuk dapat membangun dan mengoperasikan Teknologi Insenerator.

7. Belum banyak pelaku ekonomi kreatif yang menggunakan bahan baku barang bekas, contoh bungkus kopi, mie, permen atau bungkus plastik lainya.

8. Perusahaan asal bungkus makanan minuman belum bisa menerima kembali sampah yang dihasilkan, contoh PT. Danone yang memproduksi air minum kemasan tidak mau menerima kembali botol kemasan yang sudah kosong.

\section{KESIMPULAN dan SARAN}

\section{A. Kesimpulan}

Berdasarkan hasil penelitian, dapat disimpulkan perkembangan bank sampah di kota Tangerang Selatan cukup baik. Dalam waktu enam tahun (tahun 2012-2018) sudah ada 239 bank sampah dengan 8.162 nasabah. Tetapi kalau disbanding jumlah penduduk yang mencapai 1.644.899, nasabah bank sampah baru mencapai 49,62\%. Artinya, belum semua penduduk menjadi nasabah bank sampah.

Keberadaan bank sampah juga kurang efektif untuk mengatasi permasalahan sampah, hal ini dapat dilihat masih banyaknya sampah yang masih belum tertangani dengan baik.Di tepitepi jalan, di tepi-tepi sungai, di pasar-pasar tradisional. Jumlah sampah yang masuk ke Dinas Lingkungan Hidup per hari masih mencapai 15-20 pick up per hari dengan rata-rata berat 950 $\mathrm{kg} /$ pick up. Artinya sampah yang dihasilkan masih cukup tinggi dan belum dipisahkan antara sampah organik dengan sampah non organik. Selain itu, dilihat dari jumlah penduduk Tangsel yang mencapai 1.644.899 jiwa pada tahun 2017, dan jumlah nasabah bank sampah pada tahun yang sama baru mencapai 4.000 nasabah, hanya sekitar $24,31 \%$, menunjukkan prosentase yang kecil.

\section{B. Saran}

1. Perlunya sosialisasi berkelanjutan kepada masyarakat tentang program minim sampah dan peduli lingkungan yang bersih dan sehat.

2. Memberikan penyuluhan pada masyarakat, bahwa peran aktif masyarakat dalam menyelesaikan permasalahan sampah sangat dibutuhkan.

3. Merubah paradigma masyarakt bahwa kehadiran bank sampah untuk membantu mengurangi sampah di TPA benar-benar difungsikan, tidak semata-mata meimbun sampah agar dapat dijadikan uang.

4. Menggerakkan bank sampah agar tidak hanya berfungsi 3R (Reuse, Reduce, Recycle) tetapi sebagai media untuk menggerakkan dan pemberdayaan masyarakat dengan program ekonomi kreatif yang menggunakan bahan bekas (sampah non organik) agar mempunyai nilai guna dan nilai ekonomis. 
JURNAL ILMIAH ILMU MANAJEMEN

5. Pemerintah menyelenggarakan program pelatihan untuk pemberdayaan masyarakat berbasis ekonomi kreatif.

6. Pemerintah setempat menindak tegas masyarakat yang membuang sampah sembarangan.

\section{DAFTAR PUSTAKA}

Anih Sri Suryani. 2014. Peran Bank Sampah Dalam Efektivitas Pengelolaan Sampah(Studi Kasus Bank Sampah Malang). Aspirasi Vol. 5 No. 1, Juni 2014

Badan Pusat Statistik. (2017). Laju Pertumbuhan Penduduk Kota Tangerang Selatan Dalam Angka. Kota Tangsel

Muhtadi. 2017. Pendampingan Bank Sampah Melati Bersih Berbasis Pemberdayaan Bagi Masyarakat Urban. Jurnal Pemberdayaan Masyarakat Media Pemikiran dan Dakwah Pembangun. Vol. 1. No.2 2017. Hal. 227-244

Notoamodjoyo. 2007. Pendidikan dan Perilaku Kesehatan. Reneka Cipta. Jakarta. Cetakan ke 2 Peraturan Menteri Lingkungan Hidup RI Nomor 13 Tahun 2012 adalah Pedoman Pelaksanaan Reduse, Reuse dan Recycle melalui Bank Sampah.

Sanusi Anwar, 2011. Metodologi Penelitian Bisnis, Disertai contoh Proposal Penelitian Bidang IImu Ekonomi dan Manajemen. Jakarta: Salemba Empat.

Sugiono. 2005. Memahami Penelitian Kualitatif. CV. Alfabeta. Bandung

Sugiyono. 2012. Metode Penelitian Pendidikan: Pendekatan Kuantitatif, Kualitatif, dan R\&D. Bandung: Alfabeta.

Sumantri. 2010. Kesehatan Lingkungan. Kencana Prenada Media Group. Jakarta 